\title{
Meta-analysis of the relationship between alcohol consumption and coronary heart disease and mortality in type 2 diabetic patients
}

Received: 27 September 2005 / Accepted: 31 October 2005 / Published online: 4 February 2006

(C) Springer-Verlag 2006

\begin{abstract}
Aims/hypothesis: This systematic review examines the relationship between alcohol consumption and long-term complications of type 2 diabetes. Meta-analyses could only be performed for total mortality, mortality from CHD, and CHD incidence, because the availability of articles on other complications was too limited. Materials and methods: A PubMed search through to September 2005 was performed and the reference lists of relevant articles examined. Among the relevant articles there were six cohort studies reporting on the risk of total mortality and/or fatal and/or incident CHD in alcohol non-consumers and in at least two groups of alcohol consumers. Results: Statistical pooling showed lower risks in alcohol consumers than in non-consumers (the reference category). The relative risk (RR) of total mortality was $0.64(95 \%$ CI $0.49-0.82)$ in the $<6 \mathrm{~g}$ /day category. In the higher alcohol consumption categories ( 6 to $<18$, and $\geq 18 \mathrm{~g} /$ day), the RRs of total mortality were not significant. Risks of fatal and total CHD were significantly lower in all three categories of alcohol consumers $(<6,6$ to $<18$ and $\geq 18 \mathrm{~g} /$ day $)$ than in nonconsumers, with RRs ranging from 0.34 to 0.75 . Conclusions/interpretation: This meta-analysis shows that, as with findings in the general population, moderate
\end{abstract}

L. L. J. Koppes $(\bowtie) \cdot$ J. M. Dekker · L. M. Bouter · R. J. Heine EMGO Institute, VU University Medical Center,

Van der Boechorststraat 7 ,

1081 BT Amsterdam, the Netherlands

e-mail: 1.koppes@vumc.nl

Tel.: +31-204448408

Fax: $+31-204448387$

\section{L. J. Koppes}

Department of Public and Occupational Health,

VU University Medical Center,

Amsterdam, the Netherlands

H. F. J. Hendriks

TNO Quality of Life, Department of Physiological Sciences,

Zeist, the Netherlands

\section{R. J. Heine}

Department of Endocrinology, VU University Medical Center, Amsterdam, the Netherlands alcohol consumption is associated with a lower risk of mortality and CHD in type 2 diabetic populations.

Keywords Alcohol - Coronary heart disease · Epidemiology $\cdot$ Meta-analysis $\cdot$ Mortality $\cdot$ Review Type 2 diabetes

Abbreviation RR: Relative risk

\section{Introduction}

It has been convincingly shown that moderate alcohol consumers have an up to $20 \%$ lower risk of CHD and mortality than alcohol non-consumers [1-5]. The mechanisms underlying this association are not fully known, but may be related to beneficial effects on haemostasis and lipid metabolism [6]. Individuals with type 2 diabetes are at high risk of CHD [7], and it has been suggested that they may benefit substantially from moderate alcohol consumption. We have previously shown that moderate alcohol consumption lowers the risk of incident type 2 diabetes [8]. However, since alcohol consumption has been associated with increased triglycerides [6], body weight [9], and blood pressure [10, 11] it may have adverse consequences for individuals with diabetes. In this systematic review we examined the relationship between alcohol consumption and long-term complications of type 2 diabetes. Meta-analyses could only be performed for total mortality, CHD mortality and CHD incidence, because the availability of articles on other complications was too limited.

\section{Materials and methods}

Articles included were found through a PubMed search of literature published until 27 September, 2005. The references in included articles and relevant reviews [12-17] were checked for additional studies of interest. Included were original peer-reviewed publications on observational cohorts or nested case-control studies in type 2 diabetic populations 
Table 1 Included studies and their characteristics

\begin{tabular}{|c|c|c|c|c|c|c|c|c|}
\hline Source & Study title & Sex & $\begin{array}{l}\text { At risk } \\
(n)\end{array}$ & $\begin{array}{l}\text { Follow-up } \\
\text { (years) }\end{array}$ & $\begin{array}{l}\text { Alcohol } \\
\text { use } \\
\text { (g/day) }\end{array}$ & $\begin{array}{l}\text { RR of total } \\
\text { mortality } \\
(95 \% \mathrm{CI})\end{array}$ & $\begin{array}{l}\text { RR of CHD } \\
\text { mortality } \\
(95 \% \mathrm{CI})\end{array}$ & $\begin{array}{l}\text { RR of incident } \\
\text { CHD } \\
(95 \% \mathrm{CI})\end{array}$ \\
\hline \multirow{2}{*}{$\begin{array}{l}\text { Valmadrid et al. } \\
1999 \text { [28] }\end{array}$} & & & & & 7.5 & $\begin{array}{l}0.47 \\
(0.33-0.69)\end{array}$ & $\begin{array}{l}0.44 \\
(0.23-0.84)\end{array}$ & \\
\hline & & & & & 21.0 & $\begin{array}{l}0.49 \\
(0.33-0.74)\end{array}$ & $\begin{array}{l}0.21 \\
(0.09-0.48)\end{array}$ & \\
\hline \multirow{3}{*}{$\begin{array}{l}\text { Solomon et al. } \\
2000[30]\end{array}$} & & & & & 10.0 & & & $\begin{array}{l}0.38 \\
(0.21-0.67)\end{array}$ \\
\hline & & & & & 14.6 & & $\begin{array}{l}0.43 \\
(0.21-0.88)\end{array}$ & \\
\hline & & & & & 22.5 & & & $\begin{array}{l}0.56 \\
(0.31-0.99)\end{array}$ \\
\hline \multirow[t]{4}{*}{$\begin{array}{l}\text { Ajani et al. } \\
2000[29]\end{array}$} & $\begin{array}{l}\text { Physicians' Health } \\
\text { Study }\end{array}$ & M & 2790 & 5.5 & 0.0 & $X$ & 1.00 & X \\
\hline & & & & & 0.9 & & $\begin{array}{l}1.11 \\
(0.66-1.89)\end{array}$ & \\
\hline & & & & & 6.9 & & & $\begin{array}{l}0.75 \\
(0.45-1.26)\end{array}$ \\
\hline & & & & & 18.0 & & & $\begin{array}{l}0.66 \\
(0.38-1.16)\end{array}$ \\
\hline \multirow[t]{4}{*}{$\begin{array}{l}\text { Tanasescu et al. } \\
2001 \text { [31] }\end{array}$} & $\begin{array}{l}\text { Health Profes- } \\
\text { sionals } \\
\text { Follow-up Study }\end{array}$ & $\mathrm{M}$ & 2419 & 10 & 0.0 & $X$ & 1.00 & 1.00 \\
\hline & & & & & 3.0 & & $\begin{array}{l}0.79 \\
(0.44-1.41)\end{array}$ & $\begin{array}{l}0.78 \\
(0.52-1.15)\end{array}$ \\
\hline & & & & & 15.0 & & $\begin{array}{l}0.59 \\
(0.29-1.21)\end{array}$ & $\begin{array}{l}0.62 \\
(0.38-1.00)\end{array}$ \\
\hline & & & & & 36.0 & & $\begin{array}{l}0.45 \\
(0.17-1.14)\end{array}$ & $\begin{array}{l}0.48 \\
(0.25-0.94)\end{array}$ \\
\hline \multirow[t]{4}{*}{$\begin{array}{l}\text { de Vegt et al. } \\
2002[26]\end{array}$} & Hoorn Study & $\begin{array}{l}\mathrm{M} \& \\
\mathrm{~F}\end{array}$ & $659^{*}$ & 6 & 0.0 & 1.00 & $\mathrm{X}$ & $\mathrm{X}$ \\
\hline & & & & & 5.0 & $\begin{array}{l}0.62 \\
(0.38-1.02)\end{array}$ & & \\
\hline & & & & & 20.0 & $\begin{array}{l}0.97 \\
(0.56-1.68)\end{array}$ & & \\
\hline & & & & & 45.0 & $\begin{array}{l}1.05 \\
(0.53-2.06)\end{array}$ & & \\
\hline
\end{tabular}


Table 1 (continued)

\begin{tabular}{|c|c|c|c|c|c|c|c|c|}
\hline Source & Study title & Sex & $\begin{array}{l}\text { At risk } \\
(n)\end{array}$ & $\begin{array}{l}\text { Follow-up } \\
\text { (years) }\end{array}$ & $\begin{array}{l}\text { Alcohol } \\
\text { use } \\
\text { (g/day) }\end{array}$ & $\begin{array}{l}\text { RR of total } \\
\text { mortality } \\
(95 \% \mathrm{CI})\end{array}$ & $\begin{array}{l}\text { RR of CHD } \\
\text { mortality } \\
(95 \% \mathrm{CI})\end{array}$ & $\begin{array}{l}\text { RR of incident } \\
\text { CHD } \\
(95 \% \mathrm{CI})\end{array}$ \\
\hline \multirow[t]{4}{*}{$\begin{array}{c}\text { Diem et al. } \\
2003 \text { [27] }\end{array}$} & $\begin{array}{l}\text { Swiss cohort of } \\
\text { WHO } \\
\text { Multinational } \\
\text { Study of } \\
\text { Vascular Disease } \\
\text { in Diabetes }\end{array}$ & $\begin{array}{c}\text { M \& } \\
F\end{array}$ & 287 & 12.6 & 0.0 & 1.00 & 1.00 & $X$ \\
\hline & & & & & 7.5 & $\begin{array}{l}1.27 \\
(0.68-2.28)\end{array}$ & $\begin{array}{l}0.87 \\
(0.25-2.52)\end{array}$ & \\
\hline & & & & & 22.5 & $\begin{array}{l}0.36 \\
(0.09-0.99)\end{array}$ & $\begin{array}{l}0.01 \\
(0.00-0.92)\end{array}$ & \\
\hline & & & & & 45.0 & $\begin{array}{l}1.66 \\
(0.77-3.33)\end{array}$ & $\begin{array}{l}0.37 \\
(0.01-2.42)\end{array}$ & \\
\hline
\end{tabular}

*Impaired fasting glucose also included in diabetes definition $\mathrm{X}$ No information reported in the publication

on the relationship between alcohol consumption and the incidence of diabetic complications. Because a non-linear relationship was presumed, papers were included if a point estimate and an estimate of variability of the complication were presented for both alcohol non-consumers and at least two alcohol consumption categories. In cases where analyses included more or fewer covariates, those estimates that were based on the model that included the largest number of potential confounders were abstracted.

For studies that only reported ranges of alcohol consumption for the categories used, the mean of the lower and upper limits was used as the average consumption for that range, and 1.5 times the lower limit was assigned as the average consumption in the highest category. The averages of the consumption ranges that were used in a study were assigned to one of three alcohol categories: zero (reference category), $<6,6$ to $<18$ and $\geq 18 \mathrm{~g} /$ day. A standard drink contains approximately $10 \mathrm{~g}$ alcohol in Europe/Australia, $12 \mathrm{~g}$ in the USA/Canada, and $21 \mathrm{~g}$ in Japan. Pooled relative risk (RR) estimates were calculated within the three alcohol categories. More details about the methods used can be found in our meta-analysis about alcohol consumption and incident type 2 diabetes [8].

\section{Results}

Fourteen prospective studies on the relationships between alcohol consumption and long-term complications of type 2 diabetes were selected on the basis of titles and abstracts of the 467 hits from the PubMed search, and following reference checking. Four studies were not included because a dichotomous estimate of alcohol consumption was used [18-21], one study did not include a category of nonconsumers [22], and one study reported on the score of an alcoholism screening questionnaire [23]. Of the two publications from the US Physicians' Health Study, the one that did not focus specifically on alcohol consumption was not included [24]. Only one of the seven remaining publications involved the incidence and progression of retinopathy [25]. Of the other six publications (Table 1), three reported the RRs for total mortality [26-28], five for CHD mortality [27-31], and three for incident CHD [29-31]. Statistical pooling showed lower risks for these three outcomes in alcohol consumers as compared with non-consumers (Fig. 1a-c). For total mortality the RR was significantly lower in the $<6 \mathrm{~g}$ /day category only $(\mathrm{RR}=0.64,95 \%$ CI $0.49-0.82$; Fig. 1a). The risk of CHD mortality was significantly lower in all three alcohol consumption categories as compared with the alcohol nonconsumers, and was most profound in those consuming $\geq 18 \mathrm{~g} /$ day (Fig. 1b). The RR of incident CHD was significantly lower in all three drinking categories also (Fig. 1c).

\section{Discussion}

To the best of our knowledge, this is the first meta-analysis on the relationship between alcohol consumption and longterm disease complications in patients with type 2 diabetes. Alcohol consumers had a $21-36 \%$ lower RR of total mortality, and a $25-66 \%$ lower RR of total and fatal CHD than non-consumers. These relationships are stronger than those in the general population where up to $20 \%$ lower RRs are found for moderate drinkers [1-5].

In a study not included but in line with our meta-analysis, Kuusisto et al. [21] showed non-significant lower RRs of CHD in type 2 diabetic alcohol consumers than in nonconsumers. However, other studies not included were partly in contrast with our findings, suggesting an increased risk at higher consumption levels, as J-shaped relationships were found between alcohol consumption and the risk of CHD [22] and acute coronary syndromes [32]. Moreover, alcohol abuse was also found to be associated with a non-significant higher risk of CHD [18].

Limited data exist about the relationships of alcohol consumption with other disease complications in type 2 diabetes 

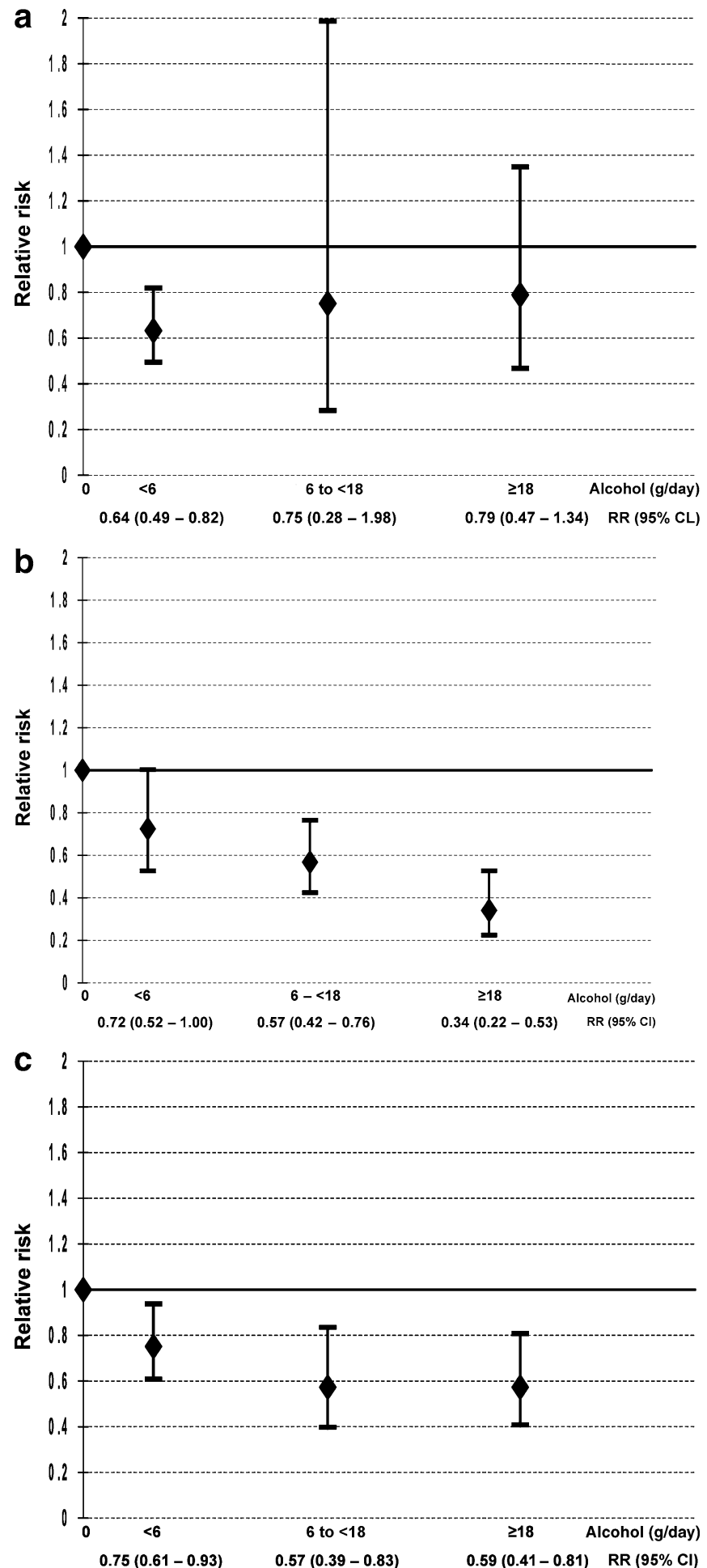

Fig. 1 Pooled relative risk estimates with corresponding 95\% CIs of total mortality (a), CHD mortality (b) and incident CHD (c) for the three alcohol consumption categories with non-consumers as the reference category

populations. The Diabetic Impotence Study showed that type 2 diabetic subjects who consumed more than $33 \mathrm{~g}$ alcohol per day had a higher risk of developing impotence and retinopathy than those who drank less $[19,20]$. In contrast, Moss et al. [25] found the lowest risks (although not significant) of incident retinopathy, progression of retinopathy, and progression to proliferative retinopathy in their highest drinking category ( $>28 \mathrm{~g} /$ day). The incidence of diabetic neuropathy was positively related with higher scores on an alcoholism screening questionnaire [23], and in regular heavy drinkers a higher prevalence of symptomatic peripheral neuropathy was found [33].

As in the general population [3], the observed mortality risk reduction related to moderate alcohol consumption in type 2 diabetic subjects could largely be attributed to the reduced risk of CHD. The beneficial effect of moderate alcohol consumption on markers of inflammation and endothelial dysfunction [34], on arterial intimal medial thickness [35], pulse wave velocity [36], HDL cholesterol [6], and insulin sensitivity [37] may all partly explain the reduced CHD risk. Since these factors are usually abnormal in individuals with type 2 diabetes, their improvement due to alcohol consumption may explain the larger CHD risk reduction compared with that in the general population. Alcohol consumption may result in hypertriglyceridaemia, hypertension and weight gain in individuals with type 2 diabetes. At moderate levels of consumption this apparently does not result in a higher risk of CHD or total mortality.

It should be noted that the number of cases included in this meta-analysis was relatively small. Because the lowest limit of the highest drinking category was only $18 \mathrm{~g} /$ day, inferences about the effects of heavy drinking by type 2 diabetic individuals cannot be made from this meta-analysis. However, some studies identified in our systematic review but not included in the meta-analyses suggest that heavy drinking may increase the risk of cardiovascular and other complications of type 2 diabetes. In conclusion, in line with findings in the general population, our results indicate that in type 2 diabetic patients moderate consumption of alcohol is associated with a lower risk of CHD and total mortality.

Acknowledgements The authors wish to thank I. Riphagen, Medical Library, Vrije University, Amsterdam, for her assistance with the literature search. This work was supported by an unconditional grant from the Alcohol Task Force of the European branch of the International Life Sciences Institute (ILSI Europe). Industry members of this task force are Allied Domecq, Brasseries Kronenbourg, Diageo, Heineken and Moët et Chandon. The opinions expressed in this article are those of the authors and do not necessarily represent the views of ILSI Europe.

\section{References}

1. Maclure M (1993) Demonstration of deductive meta-analysis: ethanol intake and risk of myocardial infarction. Epidemiol Rev $15: 328-351$

2. Corrao G, Rubbiati L, Bagnardi V, Zambon A, Poikolainen $\mathrm{K}$ (2000) Alcohol and coronary heart disease: a meta-analysis. Addiction 95:1505-1523

3. Holman CD, English DR, Milne E, Winter MG (1996) Metaanalysis of alcohol and all-cause mortality: a validation of NHMRC recommendations. Med J Aust 164:141-145

4. Bagnardi V, Zambon A, Quatto P, Corrao G (2004) Flexible meta-regression functions for modeling aggregate dose-response data, with an application to alcohol and mortality. Am J Epidemiol 159:1077-1086 
5. Gmel G, Gutjahr E, Rehm J (2003) How stable is the risk curve between alcohol and all-cause mortality and what factors influence the shape? A precision-weighted hierarchical metaanalysis. Eur J Epidemiol 18:631-642

6. Rimm EB, Williams P, Fosher K, Criqui M, Stampfer MJ (1999) Moderate alcohol intake and lower risk of coronary heart disease: meta-analysis of effects on lipids and haemostatic factors. BMJ 319:1523-1528

7. Haffner SM, Lehto S, Ronnemaa T, Pyorala K, Laakso M (1998) Mortality from coronary heart disease in subjects with type 2 diabetes and in nondiabetic subjects with and without prior myocardial infarction. N Engl J Med 339:229-234

8. Koppes LLJ, Dekker JM, Hendriks HFJ, Bouter LM, Heine RJ (2005) Moderate alcohol consumption lowers the risk of type 2 diabetes - a meta-analysis of prospective observational studies. Diabetes Care 28:719-725

9. Wannamethee SG, Shaper AG (2003) Alcohol, body weight, and weight gain in middle-aged men. Am J Clin Nutr 77:1312-1317

10. Kato I, Kiyohara Y, Kubo M et al (2003) Insulin-mediated effects of alcohol intake on serum lipid levels in a general population. The Hisayama Study. J Clin Epidemiol 56:196-204

11. Thadhani R, Camargo CA, Stampfer MJ, Curhan GC, Willett WC, Rimm EB (2002) Prospective study of moderate alcohol consumption and risk of hypertension in young women. Arch Intern Med 162:569-574

12. Tanasescu M, Hu FB (2001) Alcohol consumption and risk of coronary heart disease among individuals with type 2 diabetes. Curr Diab Rep 1:187-191

13. Howard AA, Arnsten JH, Gourevitch MN (2004) Effect of alcohol consumption on diabetes mellitus - a systematic review. Ann Intern Med 140:211-219

14. Zilkens RR, Puddey IB (2003) Alcohol and type 2 diabetesanother paradox? J Cardiovasc Risk 10:25-30

15. van de Wiel A (2004) Diabetes mellitus and alcohol. Diabetes Metab Res Rev 20:263-267

16. Bell DSH (1996) Alcohol and the NIDDM patient. Diabetes Care 19:509-513

17. Avogaro A, Tiengo A (1993) Alcohol, glucose-metabolism and diabetes. Diabetes Metab Rev 9:129-146

18. Rosengren A, Welin L, Tsipogianni A, Wilhelmsen L (1989) Impact of cardiovascular risk factors on coronary heart disease and mortality among middle aged diabetic men: a general population study. BMJ 299:1127-1131

19. Young RJ, Mcculloch DK, Prescott RJ, Clarke BF (1984) Alcohol-another risk factor for diabetic-retinopathy. BMJ 288:1035-1037

20. Mcculloch DK, Young RJ, Prescott RJ, Campbell IW, Clarke BF (1984) The natural-history of impotence in diabetic men. Diabetologia 26:437-440

21. Kuusisto J, Lempiainen P, Mykkanen L, Laakso M (2001) Insulin resistance syndrome predicts coronary heart disease events in elderly type 2 diabetic men. Diabetes Care 24:1629-1633

22. Soinio M, Laakso M, Lehto S, Hakala P, Ronnemaa T (2003) Dietary fat predicts coronary heart disease events in subjects with type 2 diabetes. Diabetes Care 26:619-624
23. Adler AI, Boyko EJ, Ahroni JH, Stensel V, Forsberg RC, Smith DG (1997) Risk factors for diabetic peripheral sensory neuropathy-results of the Seattle Prospective Diabetic Foot Study. Diabetes Care 20:1162-1167

24. Lotufo PA, Gaziano JM, Chae CU et al (2001) Diabetes and allcause and coronary heart disease mortality among US male physicians. Arch Intern Med 161:242-247

25. Moss SE, Klein R, Klein BEK (1994) The association of alcoholconsumption with the incidence and progression of diabeticretinopathy. Ophthalmology 101:1962-1968

26. de Vegt F, Dekker JM, Groeneveld WJ et al (2002) Moderate alcohol consumption is associated with lower risk for incident diabetes and mortality: the Hoorn Study. Diabetes Res Clin Pract 57:53-60

27. Diem P, Deplazes M, Fajfr R et al (2003) Effects of alcohol consumption on mortality in patients with Type 2 diabetes mellitus. Diabetologia 46:1581-1585

28. Valmadrid CT, Klein R, Moss SE, Klein BEK, Cruickshanks KJ (1999) Alcohol intake and the risk of coronary heart disease mortality in persons with older-onset diabetes mellitus. JAMA 282:239-246

29. Ajani UA, Gaziano JM, Lotufo PA et al (2000) Alcohol consumption and risk of coronary heart disease by diabetes status. Circulation 102:500-505

30. Solomon CG, Hu FB, Stampfer MJ et al (2000) Moderate alcohol consumption and risk of coronary heart disease among women with type 2 diabetes mellitus. Circulation 102:494-499

31. Tanasescu M, Hu FB, Willett WC, Stampfer MJ, Rimm EB (2001) Alcohol consumption and risk of coronary heart disease among men with type 2 diabetes mellitus. J Am Coll Cardiol 38:1836-1842

32. Pitsavos C, Makrilakis K, Panagiotakos DB et al (2005) The Jshape effect of alcohol intake on the risk of developing acute coronary syndromes in diabetic subjects: the CARDIO2000 II Study. Diabet Med 22:243-248

33. Mcculloch DK, Campbell IW, Prescott RJ, Clarke BF (1980) Effect of alcohol intake on symptomatic peripheral neuropathy in diabetic men. Diabetes Care 3:245-247

34. Shai I, Rimm EB, Schulze MB, Rifai N, Stampfer MJ, Hu FB (2004) Moderate alcohol intake and markers of inflammation and endothelial dysfunction among diabetic men. Diabetologia 47:1760-1767

35. Cooper DE, Goff DC, Bell RA, Zaccaro D, Mayer-Davis EJ, Karter AJ (2002) Is insulin sensitivity a causal intermediate in the relationship between alcohol consumption and carotid atherosclerosis? The insulin resistance and atherosclerosis study. Diabetes Care 25:1425-1431

36. Wakabayashi I, Kobaba-Wakabayashi R, Masuda H (2002) Relation of drinking alcohol to atherosclerotic risk in type 2 diabetes. Diabetes Care 25:1223-1228

37. Kiechl S, Willeit J, Poewe W et al (1996) Insulin sensitivity and regular alcohol consumption: large, prospective, cross sectional population study (Bruneck study). BMJ 313:1040-1044 